\title{
9. Hierarchy, Precedence and Values: Scopes for social action in Ngadhaland, Central Flores
}

\author{
Olaf H. Smedal
}

While anthropologists have been alerted to the regimented and thwarted research which a strict adherence to regionally developed 'gatekeeping concepts' (Appadurai 1986) may effect, it is neither necessarily more productive nor less hazardous to export/import such concepts across regions. As a case in point, James Fox has remarked (1989:51-53, 1994) that there are inherent difficulties in applying Dumont's concept of hierarchy (1980) to societies of eastern Indonesia. These do not have the encompassing religious coherence that Dumont has attributed to India; for this reason, hierarchy cannot be described as a single principle nor identified with a specific opposition, such as pure and impure. In Eastern Indonesia there are a variety of contending oppositions that are of considerable importance to the definition of hierarchy and it is not one opposition but the interplay among various oppositions that gives rank to elements of a whole in the relation to the whole (Fox 1989:51).

The validity of this general assessment of eastern Indonesian societies depends perhaps as much on the theoretical bent and analytical perseverance of the investigator as it does on the nature of the 'contending oppositions' themselves. But be that as it may, attempts to conflate hierarchy and stratification, to link the one to the other, or to insist that one generates the other (see several articles in the Transformations of hierarchy volume of History and Anthropology [Jolly and Mosko 1994]) - despite Dumont's expressed formulations to the contrary (for example, 1980:65-66), is perhaps counter-productive. Anthropologists have long been accustomed to the possibility that not only indigenous terms but analytical ones as well can turn out on inspection to be polythetically constituted (Needham 1975). We have been warned that failure to recognize this may cause confusion and, correspondingly, pointless theoretical dispute. Will an insistence on pushing 'stratification' into 'hierarchy' lead to sharper models, or will it muddle them?

My own position on this issue is agnostic. But if my tentative skepticism is not misplaced, then we may be well advised to simply accept Dumont's definition of the concept and the accompanying strictures - but with a proviso: to regard his definition as nomological - not essential. That way we can at least avoid a dialogue of the deaf. Thus I shall not use this particular term in the following, 
except when its meaning is unambiguously Dumontian, explicitly discussed, or when I quote or paraphrase other authors.

Since my argument, such as it is, is principally informed by data derived from field research among the Ngadha ethno-linguistic group, central Flores, I begin with a rough sketch of Ngadha social organization. ${ }^{1}$

Those who are familiar with (especially eastern) Indonesian societies will not be astonished to learn that Ngadha evince a pervasive concern with scalar, seriated classification. Houses are placed in ranked classes, plots and tracts of land are divided into ordered categories, and persons are ascribed to social strata. Asking what these classifications are basically about, I shall elaborate the programmatic answers I offer now as I go along.

With respect to Houses ${ }^{2}$ and lands the classification is most abstractly to do with what one could label seniority, or authority; 'an ordering on a gradient of stepped differences from low to high' as Adams (1974:328) puts it with regard to Sumba intellectual order - the most apt word for the concept I wish to convey is perhaps 'precedence', as Lewis (1988) has used it. And the primary idiom employed, implicitly or explicitly, in this discourse of gradient order or degrees of precedence is that of 'origin'. The closer the classified entity (House, land) is to the origin (conception, inception) - of which it is in a sense merely a later version, pale copy, or weak reflection - the grander, loftier, mightier, more important, and more valued it is held to be.

Central to understanding Ngadha social organization are first of all the categories sa'o ('House') and woé ('House coalition network'), into which every Ngadha person is born. Every person is, accordingly, referred to as the 'child' (ana) of such and such House and woé. Whereas 'House' is an accurate translation of the Ngadha $s a^{\prime} o$, the (provisional) gloss 'House coalition network' for woé is mine - other ethnographers (Bader 1953; Arndt 1954) have used instead 'clan' or other terms which misleadingly evoke 'descent' as the sole principle for recruitment. ${ }^{3}$ Second is a principle of social stratification. Ngadha are divided into three strata: nobles or aristocrats, commoners, and (former) slaves, between which marriage is strictly regulated. With a view to the overall context of the discussion that follows, it should be pointed out that there is no record of any central institutions of political or religious power in Ngadhaland prior to the moderately successful installation of 'rajas' following the establishment of Dutch military control in the early twentieth century.

\section{Houses}

As seems to be the case in a great number of eastern Indonesian societies Ngadha Houses are simultaneously dwellings, corporate estates, ancestral abodes, ritual centres and repositories of heirloom sacra. They are also frequently partners in exchanges predicated on marriage. In short, Ngadha Houses are - if any such 
thing exists - prototypical Houses in the Lévi-Straussian (1982) definition of that term. As Fox formulated it in 1980, 'house' 'is a fundamental cultural category used in eastern Indonesia to designate a particular kind of social unit'; its characteristics including an idea of localization or origin, a strictly stipulated physical structure, elder/younger hierarchical relations - yet not necessarily gender-specific, and a notion of a 'flow of life' (usually women) between the houses (Fox 1980:11-12). I must leave out the ethnographic details which show that in contrast to comparable units elsewhere in eastern Indonesia the Ngadha House is not 'a primary descent group' (Fox 1988:xii), but want to stress that traditional, strictly stipulated architecture is practised in Ngadhaland with remarkable vigour.

A visitor to a traditional Ngadha village (nua) will notice that at least two Houses look slightly different from the others. One will have a tiny model of a house, called ana ié, at the centre of the ridge of its roof, the other a human-like figurine, called ata, at the corresponding place. These Houses are the two initial ones of any one woé. As far as I know every Ngadha woé will have minimally these two Houses. The one with the little house on it is called $s a^{\prime} o$ (or saka) $p u^{\prime} u$, the other sa'o (or saka) lobo. ${ }^{4}$ These designations indicate the place allotted a male elder of the House in question when a new ngadhu or 'two-pronged sacrificial pole' is carried into the village. This is a rare event; a ngadhu may stand for a century or more and the political act of instituting a new woé is not a frequent one. The more senior of these two Houses - and positions - is $p u^{\prime} u$. When the ngadhu — placed horizontally atop a huge bamboo scaffold - is carried from the place where it has been carved into the village, a war-clad, prominent male affiliate of the $s a^{\prime} o u^{\prime} u$ stands on the trunk/root part of it (which enters the village first) while an affiliate of the $s a^{\prime} o$ lobo stands atop its tip end.

Having pointed out that 'at least' two Houses look different from the others, I must emphasize that many villages include Houses of more than one woé. Where this is the case there may be a corresponding number of $s a^{\prime} o p^{\prime} u$ and $s a^{\prime} o$ lobo pairs - and indeed also of pairs or more accurately couples of ngadhu (a sacrificial pillar, the manifestly 'male' representation of the woé founding ancestor) and bhaga (a miniature house, the manifestly 'female' representation of the woé founding ancestress) at the centre of the village plaza. Thus a visitor to a Ngadha village will normally know at a glance the number of woé its residents are affiliated to - it suffices to count the number of Houses with a little house on the ridge purlin, or the number of Houses with a figurine, or the number of ngadhu, or the number of bhaga. It must be pointed out, however, that this 'normal' situation does not always prevail. Firstly, for certain (chiefly economic) reasons any one House, ngadhu, and/or bhaga in a village is possibly yet to be put up; secondly, a village may include 'cadet' Houses of woé centred elsewhere. I shall comment further upon the ngadhu/bhaga 'emblematic couple' shortly, but should point out here that they, together with certain House and woé 
heirlooms, belong to an unnamed Ngadha category of inalienable sacra. These are physical objects possessing to a degree certain attributes commonly ascribed to sentient beings; they are frequently conceptually gendered, they can feel abandoned, and experience hunger - especially for the blood of a sacrificial animal.

Decisions affecting the woé in its entirety are ultimately the responsibility of its 'trunk House' ( $\mathrm{sa}^{\prime} \mathrm{o} \mathrm{pu}^{\prime} u$ ), the rightful residents (office-holders, stewards) of which are said to have 'full rights' (ha benu). Marginally second in prominence is the 'tip House' ( $s a^{\prime} o$ lobo). Accordingly, woé land is divided into trunk (House) and tip (House) land. While decisions on land use can be made with relative autonomy by any named House that possesses at least one symbolic 'House digging stick' (su'a sa'o), no woé land can be sold without the explicit approval of the trunk House. ${ }^{5}$

I shall discuss aspects of 'marriage' and related topics below, but should make clear at this point that the woé division into trunk and tip sides is never invoked with respect to past, current, or contemplated marriages; there are no moieties in Ngadha social organization.

Less prominent than the trunk and tip Houses are the wua gha'o and, subordinated to these again, kaka. These are all named cadet Houses and are collectively referred to as sa'o mézé, lésa mézé (great Houses), sa'o ngaza (named Houses) or lanu. The term wua gha'o exploits a fundamental Ngadha idea - one that will not surprise anyone familiar with ethnographies of eastern Indonesia — that human relationships are mostly asymmetrical: wua means 'fruit', 'child'; gha'o, equivalent to the Bahasa Indonesia (BI) term géndong, means 'carry on the small of the back or the hip, supported by the waist and one arm, often with the help of a cloth sling' (Echols and Shadily 1990:184). The relationship between a sa'o mézé and its wua gha'o is thus metaphorically expressed as one between parent and child. The meaning of kaka is less specific, but among its many possible glosses are 'member', 'belong to', 'support', 'protect' and 'assist' (Arndt 1961:230). Ngadha men and women often explain to the investigator that just as large upright stones need smaller ones next to them in order not to fall over, men depend on women, and trunk Houses need the support of wua gha'o and $k a k a$. Another conventional indigenous synecdoche for the structure of the House coalition network (woé) is the ngadhu itself. As a sacrificial pillar at which woé affiliates kill water buffaloes in ritual it is the emblem for the woé in its entirety, although this emblem is ineffective without the bhaga complementing it. The ngadhu's trunk and tip stand for the trunk and tip Houses or, to put it in an equally valid way, the labels 'trunk House' and 'tip House' themselves refer directly back to the high-profile ritual when senior males of each House ride atop either end of the $n g a d h u$, as just mentioned. The $n g a d h u$ 's branches - 
and the branches of its roots - represent the two sets of wua gha'o and kaka Houses. ${ }^{6}$

I have already mentioned that the ngadhu/bhaga couple are replicated in yet another set of miniatures: the ata/ana ié atop the two founding Houses of the woé. It is worth noting that the 'male' trunk House is adorned with the minuscule House model while the 'female' tip House features the figurine.

I should also reiterate that every House 'belongs' to one of the two sides: to the tip side or the trunk side. The entire woé is as it were split down, or along, the middle. Importantly, only when the one side is completely extinct can affiliates from the other move in to become permanent dwellers of those Houses. The main point is that every House (and person and plot of land) belongs to either the trunk or the tip side, and that each House relates to any other of its side in an order of precedence.

By the same token, the size of a traditional House - its physical proportions - must also correspond to its position in this scheme of precedence. Largest of any woé House is $s a^{\prime} o p^{\prime} u$, the second largest is $s a^{\prime} o$ lobo. And Houses of each consecutive level (wua gha'o, kaka) must be, if only barely, smaller than the one preceding it. Moreover, socio-symbolic spatial categories, elements of construction, and a multitude of evocative carvings embossed on the House, are all salient to the many meanings of the House (cf. Smedal 2000).

With demographic growth further diversification takes place, viz. the building of subsidiary, unnamed Houses - invariably outside the traditional village compound (loka nua) — referred to as baru. ${ }^{7}$ Finally, the inhabitants of most lanu and baru build also a field house $(k e ́ k a)$ or two where they spend a great deal of time 'guarding the maize' as crops mature and tempt monkeys and wild pigs.

Notably, the number of named Houses in any one village is not fixed once and for all. But the expenses associated with the requisite ceremonies for turning an unnamed baru into a named lanu/sa'o, even when people aspire to do so, render such transformation all but impossible at present. An important reason why a great measure of organizational stability obtains in Ngadha villages, therefore, is that while politico-ritual relative autonomy is always attainable its cost is great.

Further establishment of Houses may occur when - for diverse reasons people from elsewhere come to live on and work the woé territory. These may found their own woé or, over time, be incorporated into one already existing, with their own named Houses. Hence a woé need not consist only of people that are either consanguineally or affinally related. Conversely, just as Houses may be incorporated from the outside (a practice reminiscent of adoption) they may 
of their own accord break loose and establish their own woé, complete with ngadhu and bhaga, although, as just noted, this is economically prohibitive.

\section{Land}

It would take me too far afield to detail how Ngadha in various ways link land with collectives: woé and Houses, but a few comments are in order. Very summarily, there are three categories of woé land: the nominally primordial 'base rock and solid earth' land; secondly 'land softened by digging sticks' — this refers to territory over which Houses have all but total control; and thirdly 'rows of maize and lines of sugarcane' land - plots over which households have usufruct rights. Furthermore, while private ownership to land is recognized, it is so only to a limited extent. It has almost always come into being as a result of individual, not collective, effort (or transgression). Such land may be inherited - as private property - by male and female offspring alike, and can subsequently be put up for sale. But with succeeding generations the distinction between private and collective will blur. What was once 'private' becomes first joint, then collective - absorbed into the House estate, though not into that of the woé - yet the names of tracts of land and the narratives of how the plots were acquired are preserved in House lore.

Still, there is no mistaking the profound conceptual difference between the two. Woé land is in principle (if not, for historical reasons, in practice) the sine qua non for the woé itself. Stories relate how the woé came to reside in and move between specific localities, and how the land came to be woé land in the first place. These narratives are by definition tied to the establishment of the trunk and tip Houses.

\section{People}

Having discussed so far Houses and land, I turn now to the principle by which people are classified. What is at play when a Ngadha says that someone is 'noble', 'commoner', 'slave'? Ngadha themselves (and not only nobles) answer that rank is ultimately to do with morals and responsibility. Whoever is classified as 'noble' is obliged to think before speaking, is expected to consider the many sides of an issue, to be generous, and to have regard also for the needs and interests of others. Most Ngadha people, who have probably never heard the phrase noblesse oblige would recognize its sense immediately. In Ngadhaland it translates into an expectation among nobles and commoners alike that nobles - particularly and most conspicuously the men - assume positions of sometimes severe but usually benign authority and responsibility in community affairs. At the level of personal behaviour standards the nobles - men as well as women but women especially - are subject to a plethora of prescriptions and proscriptions. These moral regulations are rigorously sanctioned by fellow nobles, often near kin. Whoever transgresses is scolded, ridiculed, or deranked. And in Ngadhaland 
the only direction social mobility can take - along this traditional axis - is downwards. Above all, therefore, the symbolic capital of Ngadha nobles is moral capital.

Commoners, on the other hand, are the ordinary folk whose behaviour is less severely scrutinized, whom the nobles 'protect' and who in turn 'support' the nobles. Again, an image commonly employed is of a large, upright stone toppling over unless propped up by smaller ones on either side. The (former) slaves are not actually integral to these fundamental categories of two classes of freemen. In part descended from captives taken in past wars, in part from commoners (and no doubt nobles, too) who once plummeted into debt bondage, they are unaccounted for in myth and legend. But if the division between nobles and commoners is fundamental it is so partly because it is not primordially given it took place in myth. It explains how things have become what they now are, not how they were to begin with. It is the Ngadha parallel to the Fall, but instead of ascribing the Change to the violation of God's command not to eat the fruit of the Tree of Knowledge it ascribes it to the brother's sexual knowledge of his sister; a transgression of something social, not divine (see Smedal 2009).

In concluding this brief outline of Ngadha social organization I should state how relationships are structured. Unlike other eastern Indonesian ethno-linguistic groups on record, the Ngadha are known to reckon kinship cognatically and have been described as practising no form of affinal alliance (Barnes 1980). Hence, also in contrast to other eastern Indonesian groups, Ngadha do not conceptually contrast between 'wife-givers' and 'wife-takers'; marriage within the woé and within the House is permitted - cross cousins and parallel cousins are terminologically lumped together and may all marry (Smedal 2002). Exchanges in connection with marriage between Houses ('bridewealth') are decisive in determining post-marital residence and, consequently, any one person's House affiliation. Yet these interdependent exchanges and practices (uxorilocality/matrilateral affiliation, and virilocality/patrilateral affiliation) exhibit extremely clear, predictable and geographically localisable patterns, effectively generating zones where 'choice' is ruled out in practical, economic terms - though not in principle.

A concern with origins, therefore, and a drive for morally acceptable behaviour: these would appear to be two sources of gravitational pull for Ngadha representations. But ultimately the latter is eclipsed by the former. For however admirable one's behaviour may be it is ephemeral and therefore worth little compared with the ultimate authority that derives from origins. Acts can affirm and attest to claims of bonds with origins but they cannot replace them, or, at least not directly. Certain acts, moving now from the domain of morals to the neighbouring and sometimes overlapping one of politics, are carried out precisely in an attempt to replace certain bonds and tales of origins with others; 
transforming and projecting along the way present feats into former ones. Successful ascendance to politico-ritual leadership in non-literate societies, as Howell (1991), for example, has demonstrated for the northern Lio further east on Flores, depends on the acceptance of such reformulations of the past. It is, I think worth stressing, that the operative word here is 'acceptance'.

\section{Asymmetry: hierarchy? stratification? power? exploitation?}

I begin this section by emphasizing the important difference between those social systems where holders of spiritual or secular power live, as it were, for free (or at least nearly so), and those where this is not the case - that is, the contrast between those social systems where the livelihood of political or religious leaders is provided by others, and those where political and ritual office does not entail exemption from regular, productive labour (see Sahlins 1974). Ngadha nobles, who constitute a social stratum or segment — not a class in the Marxian sense - can hardly be said to receive tribute in any substantial sense. And specialists, noble or not, can only claim such 'tribute' that might just as accurately be termed 'payment' for services rendered. Examples of such payments would include the fees male wood carvers charge for their work on Houses, and the remunerations female weavers ask for pieces of indigo cloth. While this is the gist of the matter, a modifying remark is in order.

Houses and woé are usually land-holding corporations and often lease land to non-affiliates. Importantly, these corporations are no less land-holding units in the event that its inhabitants/stewards/care-takers are commoners. Moreover, Ngadha land rent - as far as swidden agriculture and horticulture are concerned - is negligible. Regardless of the size of the plot in question (commonly between half a hectare and a hectare) the household renting land is obliged to present once a year - a measure of hulled rice (approximately three kilograms), a fowl, and one or two bottles of palm gin to the relevant House (now in its role as landlord, mori tana 'lord of the land'). In the unlikely event that all three items were purchased they would represent a modest monetary value: in 1993 less than US\$3. Landowners and tenants alike describe this as a token payment. Still, in addition to this rent in 'pure form', landless peasants are required to participate in the pooling of resources when on occasion a landholding woé House is rebuilt. Minimally each household must bring a medium-sized pig for the festive inauguration of the House when sometimes a couple of hundred people are fed, but tenants may also be asked to contribute food for the builders while they are at work, or to assist in the construction of the House. ${ }^{8}$

Usurpation - routinely attributed as endemic among those 'at the top' is difficult to identify among the Ngadha. Indeed, and at the risk of appearing the naïve observer, I would hazard the assertion that usurpation or exploitation cannot be ascribed to the 'system'. To the degree that such traits can be observed at all, they are attributable rather to specific persons in specific positions vis-à-vis 
specific others. To take just one example: intelligent, hard-working men who are able to set aside some of their earnings can turn into ruthless moneylenders; the standard yearly rate of interest being 100 per cent. Thus I am neither suggesting that interpersonal conflict is absent, nor that relations between more inclusive social units (Houses, woé, allied woé or federated villages) are inherently harmonic. But the roots of politico-economic conflict in Ngadhaland are not, I submit, buried in the system of social stratification. As I have tried to explicate, there is no political, economic or ritual power inhering in nobility as such, nor is it possible to achieve noble status through social action, hence there is no vying for such status nor can there be. Another way of putting this is to say that there is no ready channel through which moral capital can be converted to economic capital or vice versa.

While it may make sense with respect to certain social formations elsewhere in the Austronesian world to say that ascribed rank is no less than achieved rank a claim, a political resource which actors deploy and which must be backed by achievement, and, more sweepingly, that a given social order (including, presumably, its value system) is always a contested one (Jolly 1994:384; Otto 1994), the general applicability of such statements is questionable. There is no lack of contestable claims in Ngadha social life (to plots of land, for example, to items of bridewealth, or to House affiliation), but claims to nobility are not among them. I have already tried to show why there is little reason to 'claim' noble rank, for example. When I presently explain how rank is produced and reproduced it will become clear, I hope, that such claims are either legitimate and accepted or illegitimate and absurd.

But before I do I want to add a brief comment on the expression 'contestable' just employed because an unreflected, common sense use of it may blur a distinction in meaning which I think is important to be clear about. The distinction I have in mind is parallel to that between 'contesting' and 'competing'. It is true that in everyday language these two terms are nearly synonymous. Yet there is a vast difference between contesting a value and competing in terms of $i t$. In the second case the objective is to seek acceptance for a claim phrased in established terms. In the first case the objective is to replace one value with another by seeking acceptance for a claim phrased in terms alternative to those currently acknowledged. The importance of the difference lies in that only the former effort, when successful, alters the value system - and potentially the social order as well. The second, in contrast, confirms them. So, when Ngadha speakers 'contest' a land claim by referring to their seniority or precedence with respect to origins, they are more accurately competing for land in terms of a recognized value - origin proximity - which thereby becomes all the more entrenched. 


\section{The production and reproduction of ranked persons}

In many Ngadha traditional domains there are few if any aristocrats left. This is so partly because there is no mechanism by which a commoner can be promoted to noble status but several by which a noble can be relegated to commoner status, and partly because all over Ngadhaland one encounters a version of a principle of preferential hypergamy which affects a surplus of marriageable women at the top with the consequence that very few women give birth to nobles.

The general rule in Ngadhaland is that a noble man may marry a noble woman, a commoner man may marry a commoner woman, and a noble man may marry a commoner woman. Hence, if a man and a woman of these reciprocal strata engage in sexual play, and if neither of them is already betrothed or married, no rule may be invoked to prevent their subsequent marriage - although other factors (such as genealogical proximity, relative age, or relative generational position) are relevant. But if a commoner man has sex with a noble woman the union constitutes a major breach of adat and is referred to as 'making a misstep' ( $l a^{\prime}$ a sala), a term which also denotes sexual acts between persons closely related (consanguineally or otherwise); 'incestuous' relationships. Formerly transgressors of the rule were executed, if caught. For the past seventy or eighty years, however, this execution of the couple has been performed symbolically. Besides, a major ritual must be carried out for the social person of the woman to be restored, since she is no longer noble; she is, temporarily, persona non grata. I cannot describe, let alone analyse this chilling ritual here. For the present it must suffice to say that the female transgressor simply has no place in the village social fabric until the ritual, which includes the ritual killing of a dog and two water buffaloes, has been carried out. Indeed, until then she is forbidden to enter the village plaza and any of the Houses delineating it. Afterwards, however, the couple are free to marry.

Ngadha considerations on the topic of sex between nobles and commoners are comparable to those between nobles and (former) slaves. Thus, no sanctions apply if the noble is male. In the converse case the woman suddenly fallen from nobility is banished from the House, the woé, and the village she was born into, and is barred from returning until the ritual of symbolic execution has been carried out. Afterwards the transgressing woman belongs to the rank of her sexual partner for, be he commoner or slave, she has become 'like him'.

Commoner women, likewise, should not have sex with (former) slaves. Whoever does, 'becomes' of their partner's status. An important distinction between noble and commoner transgressors, however, is that only the former are referred to as having, or having committed, la'a sala. The upshot of it is that a Ngadha woman should only marry — indeed should only have sex with - a man of her own or a higher rank. 
Below I present the consequences of the Ngadha version of the principle of preferential hypergamy in tabular form, especially with a view to the frequent outcomes of sexual and marital unions, namely children - or, more precisely, for the rank of these children.

In Table 9.1, illegitimate combinations are marked by parentheses. These same combinations lead to a change, invariably negative, in the woman's rank - namely to that of her partner or 'husband' (whose rank is never affected on account of his sexual-marital liaisons) - and are marked with a division sign $\left({ }^{\prime} \div\right) \cdot{ }^{9}$

\section{Table 1. Parentage, filiation and social stratification}

\begin{tabular}{|c|c|c|}
\hline $\begin{array}{c}\text { Father } \\
\text { noble } \\
\text { noble }\end{array}$ & $\begin{array}{c}\text { Mother } \\
\text { noble } \\
\text { commoner } \\
\text { noble }\end{array}$ & $\begin{array}{c}\text { Child } \\
\text { noble } \\
\text { commoner } \\
\text { slave }\end{array}$ \\
\hline (commoner) & (noble) $\div$ & commoner \\
commoner & commoner & commoner \\
commoner & slave & slave \\
\hline (slave) & (noble) $\div$ & slave \\
(slave) & (commoner) $\div$ & slave \\
slave & slave & slave \\
\hline
\end{tabular}

Of the nine conceivable combinations, six are permitted, three prohibited. Two of the latter concern noble women - who have only one legitimate option: to marry a noble man. A noble woman known to have had sex with a man of commoner or slave extraction is promptly and irreversibly demoted to the rank of her partner, whether or not the union produced a child. ${ }^{10}$ Such strict limitation in the options for potential partners is conversely the case for men of slave status; they can only legitimately have sex with or marry women of their own rank. A noble man, in contrast, may have sex with, or marry, women of any rank. Similar multiple options are legitimately available also for women of slave status.

Of the six unions considered legitimate it will be seen that only one can result in a noble child, two in a commoner child, and three in a slave child. It is evident also that only one union among all nine would generate a noble child. And of the three illegitimate unions resulting in a woman's loss of rank, two would produce a slave child. In other words, only legitimate unions can produce noble children, two legitimate and one illegitimate can produce commoner children, while three legitimate and two illegitimate ones can yield slave children. I formulate the tabular information in this manner deliberately, because I wish to bring out clearly a central Ngadha perception - voiced by commoners and nobles alike - that nobles, and with regard to sexual behaviour, noble women, lead morally more exacting lives than do other people. If they err they pay dearly, for there is no mechanism or practice by which their status, once having 
changed, can change back again. The formulations also accentuate the mental association in Ngadha freemen's minds between slave status and contaminating disgrace. It is to be expected, therefore, that the moral pressure exerted upon noble women by their near kin to marry noble men and no one else, in order to secure noble offspring (and to avoid public humiliation), is considerable. Nor is it surprising that given the absence of a prohibition on noble men to marry women of lower rank and the fact that such unions are unexceptional, it is too often the case that there is no suitable noble man around to marry. In many villages old, single, noble women live alone; the only remaining noble of their House they are referred to with humorous pity as 'waiting maidens' ${ }^{11}$

It should be made clear, finally, that even if a noble man has had sex with or even children by a commoner or (former) slave woman, though has not 'married' her, he can still marry a noble woman and sire noble children by her. A noble man's status, therefore, cannot be altered on account of his amorous exploits.

But although it is only the women who, on account of sexual liaisons with men of lower rank, can fall from grace, be banished, become a person of lower rank, and henceforth give birth only to persons of lower rank, noble men can or could be demoted, too, but not on grounds of inter-rank sexual transgression. The consequence of breaking one or another of the plethora of rules (often in the form of piré 'taboos') traditionally applying to the behaviour of nobles was that the transgressor immediately lost rank. This is apparently no longer so, but most of the rules and taboos are still known and one's behaviour is judged according to them. One is that a noble male, in mixed-rank company, should never walk behind commoners, another that any noble person should never take shelter under a commoner's house or field hut (although to spend time in it is all right). A third instance often quoted to me concerns the noble who, while walking across the village plaza, slips and falls into the mud. This is just the sort of thing a noble must not do and, worse, the fall is probably observed by all who happen to sit on their verandah. Now, according to Ngadha a water buffalo, insofar as it ever makes a sound, utters a nasal hoa. What the (presumably noble) mirthful onlookers say when they see the noble prostrate in the mud is precisely that; ' $h o a^{\prime}$. Or they just raise their chin, baring their throat, as a buffalo is made to do at sacrifice. What everyone understands is that unless the hapless noble immediately fetches a buffalo and kills it he is no longer considered noble.

Thus the path of the noble 'is very narrow, scarcely as wide as a reed (wako) leaf', as Arndt puts it (1929:842). One important difference between men's and women's transgressions, however, is that men are often able to rectify theirs by sacrificing a buffalo; by taking action. Women are not similarly blessed (Arndt 1960:180). ${ }^{12}$ 
What I have not discussed explicitly is politico-economic power or influence. If political clout does not inhere in or emanate from high rank as such, as I have tried to argue, then whence does it derive? The answer is that it is cultivated in a discursive field where personal knowledge, experience, prowess and achievement are all-important, and where the difference between nobles and commoners is of no matter.

Men (not women) of authority are generally referred to as mosa laki - an achieved status in Ngadhaland, although certain categories of mosa laki may have inherited the basis for that status, especially land. Among an indeterminable number of mosa laki types are the following seven:

1. mosa kaba laki wéa

a mosa laki who is rich in livestock and gold (chains)

2. mosa tana laki watu OR mosa watu laki tana

a mosa laki who owns a large plot of land

3. mosa nua laki bo'a

a mosa laki within the village (not the greatest of mosa laki; a 'local hero')

4. mosa wiwi laki lema

a mosa laki with exceptional oratorical skills

5. mosa toa laki wela

a mosa laki who frequently practices ritual killing of water buffaloes and pigs

6. $\quad$ mosa pedu laki rona OR mosa péu laki rona OR

mosa wiu laki pi'u OR mosa pedu laki pada

a mosa laki who always gives good advice to others

7. mosa po laki péra

a mosa laki able to instruct others

Now all these labels are equally applicable to males of noble and commoner rank - not to slaves, who are excluded by definition from fields of adat discourse, just as are children and the mentally infirm. There are other labels, some of them mocking or ironic, which designate puny, pretentious, ineffectual, incapable or sexually irresponsible 'mosa laki'. And these labels, too, are as freely applied to nobles as they are to commoners.

Interestingly, the advent of Indonesian nation state institutions have altered the state of affairs I have just described. But while persons of slave extraction are sometimes employed in regency-level bureaucracies and are known to have run successfully for office in urban areas, partly because as Indonesian citizens they are as entitled to higher education as anyone else and they can thus acquire relevant qualifications, they have failed so far to make an impression in village-level politics. This is not surprising since the requisite expertise at this 
political level can be attained only by those who know village life intimately, which comprises details on historical, genealogical, personal, and, above all, adat matters.

\section{Final remarks}

In rounding off I shall make a couple of remarks only tenuously related to the Ngadha material, hoping to stimulate debate.

1. We can take it as axiomatic, I think, that no social system is totally stable, and as equally axiomatic that social scientists are interested in how social systems are maintained while they change - in continuities as well as in discontinuities. Now it appears that some analysts take it as axiomatic, too, that the threat to social stability comes from 'below', from the sub-altern. On the basis of the slim evidence I have been able to introduce here I want to propose instead that the threat to Ngadha social stratification does not come from below but from the top.

It is indeed difficult to see what interest the sub-alterns, at least the commoners (descendants of former slaves are another matter, but they constitute a very small minority) have in toppling 'the system'. The nobles do not usurp the commoners; the commoners are not exploited by the nobles. Furthermore, recall the moral standards which apply to aristocrats and which would render the life of a commoner-turned-noble - an impossible aspiration anyway, as I have explained - much more onerous than it already is. Commoner landlords and House stewards have the same social responsibilities and prerogatives as do the noble ditto, and noble peasants till the soil, harvest their crops, and raise their pigs just the way commoner peasants do. But the nobles lead lives which are under constant scrutiny.

And this is the point: Because many cannot live up to those standards, because greed may turn gamblers into paupers, because infatuations can cross social divides, because only noble women can produce noble children, because, in short, that 'reed leaf' is so very narrow, it is the actions of the nobles themselves which threaten 'the system'.

2. In my view there is a regrettable, if predictable trend in some current anthropological theorizing to bracket what might be labelled the 'structural' constraints on action and zoom in on person-centred action itself. If an exaggeration may be permitted, it is as if in an effort to 'countermand hierarchy' (Jolly 1994:385ff.), one simultaneously fails to note what is currently taken-for-granted and what-goes-without saying in any one community, society or culture.

Now there is a troublesome side to this renewed concern for individually attributable action insofar as it tends to be accompanied by a reluctance to explicate the socio-cultural horizon within which it can be effective - indeed 
make sense at all (Smedal 1992). And I wonder if the current emphasis on individuals and action and choice and instability to the (relative) exclusion of collectivities and structure and rules and stability is as anti-ethnocentric as some rhetoric would have it. It may well be that anthropologists have overplayed the differences between Us and the Exotic Other. It may well be, too, that individual ploys, stratagems and tactics in small(er)-scale societies have been underplayed, and precolonial societies have of course waxed and waned in a variety of dimensions. But it seems to me that the accelerating change many people in certain areas of the world experience, most aptly indexed perhaps by massively funded cybertechnological and biomedical innovation, is very unevenly distributed. It is also, and this is not a coincidence, observed in its purest form - continually ramifying, being recalibrated and propelled forward - in societies or ideological climates where individual choice and action have been accorded great value (Dumont 1986). In brief, I sense that the pendulum of intellectual fashion has been driven to its present extreme less by an effort to understand what is difficult to accept than by an inclination to phrase it in terms that match the turmoils of our own. It is 'we' who, probably more than anybody before us (or beside us), cannot choose not to choose, and it is 'we' who must do so among a steadily proliferating set of alternatives between which differences become as steadily difficult to discern.

Obviously, people everywhere act and choose, clearly they apprehend and 'construct' their vision of the world. But I think it cannot be stressed enough, first that this construction is not carried out in a social vacuum, but that it is subjected to structural constraints; secondly, that the structuring structures, the cognitive structures, are themselves socially structured, because they have social origins; thirdly, the construction of social reality is not only an individual enterprise, but may also become a collective enterprise (Bourdieu 1990:131). This is as true for the observed as it is for the observers.

\section{References}

Adams, Marie Jeanne

1974 Symbols of the organized community in East Sumba, Indonesia. Bijdragen tot de Taal-, Land-en Volkenkunde 130:324-347.

Appadurai, Arjun

1986 Theory in anthropology: center and periphery. Comparative Studies in Society and History 28(2):356-361.

Arndt, Paul SVD

1929 Die Religion der Ngada [Part I]. Anthropos 24:817-861.

1954 Gesellschaftliche Verhältnisse der Ngadha. Studia Instituti Anthropos Vol. 8. Wien-Mödling: Verlag der Missionsdruckerei St. Gabriel. 
1960 Opfer und Opferfeiern der Ngadha. Asian Folklore Studies 19:175-250. Tokyo: Folklore Studies [Asian Folklore Studies], Society of the Divine Word.

1961 Wörterbuch der Ngadhasprache. Fribourg, Switzerland: Pertjetakan Arnoldus, Endeh/Posieux. [Studia Instituti Anthropos 15.]

Bader, Hermann SVD

1953 Die Reifefeiern bei den Ngadha (Mittelflores, Indonesien). Mödling bei Wien: St.-Gabriel-Verlag. [St.-Gabrieler Studien 14.]

Barnes, R.H.

1980 Marriage, exchange and the meaning of corporations in eastern Indonesia. In J.L. Comaroff (ed.), The meaning of marriage payments, pp.93-124. London: Academic Press.

Bourdieu, Pierre

1990 In other words: essays towards a reflexive sociology. Trans. Matthew Adamson. Cambridge: Polity Press.

Dumont, Louis

1980 Homo hierarchicus: the caste system and its implications. (2nd edn). Chicago: The University of Chicago Press.

1986 Essays on individualism: modern ideology in anthropological perspective. Chicago: The University of Chicago Press.

Echols, John M. and Hassan Shadily

1990 Kamus Indonesia-Inggris: an Indonesian-English dictionary. Jakarta: Gramedia. 3rd edn. revised and edited by John U. Wolff and James T. Collins, in co-operation with Hassan Shadily.

Erb, Maribeth

1987 When rocks were young and earth was soft: ritual and mythology in Northeastern Manggarai. Unpublished PhD thesis. Stony brook, New York: State University of New York at StonyBrook.

Fox, James J.

1980 Introduction. In James J. Fox (ed.), The flow of life: essays on eastern Indonesia, pp.1-18. Cambridge, MA: Harvard University Press.

1988 Foreword. In E.D. Lewis, People of the source: the social and ceremonial order of Tana Wai Brama on Flores, pp.xi-xiv. Verhandelingen van het Koninklijk Instituut voor Taal-, Land- en Volkenkunde 135. Dordrecht, Holland/Providence, USA: Foris Publications. 
1989 Category and complement: binary ideologies and the organization of dualism in eastern Indonesia. In David Maybury-Lewis and Uri Almagor (eds), The attraction of opposites: thought and society in the dualistic mode, pp.33-56. Ann Arbor: University of Michigan Press.

1994 Reflections on 'hierarchy' and 'precedence'. In M. Jolly and M. Mosko (eds), Transformations of hierarchy: structure, history and horizon in the Austronesian world. History and Anthropology (Special Issue) 7:87-108.

Howell, Signe

1991 Access to the ancestors: re-constructions of the past in non-literate society. In Reidar Grønhaug, Gunnar Haaland and Georg Henriksen (eds), The ecology of choice and symbol: essays in honour of Fredrik Barth, pp.225-243. Bergen: Alma Mater.

Jolly, Margaret

1994 Epilogue: hierarchical horizons. In M. Jolly and M. Mosko (eds), Transformations of hierarchy: structure, history and horizon in the Austronesian world. History and Anthropology (Special Issue) 7:377-409.

Jolly, Margaret and M. Mosko (eds)

1994 Transformations of hierarchy: structure, history and horizon in the Austronesian world. History and Anthropology (Special Issue) 7.

Lévi-Strauss, Claude

1982 The way of the masks. Trans. Sylvia Modelski. Seattle: University of Washington Press.

Lewis, E.D.

1988 People of the source: the social and ceremonial order of Tana Wai Brama on Flores. Verhandelingen van het Koninklijk Instituut voor Taal-, Landen Volkenkunde 135. Dordrecht, Holland/Providence, USA: Foris Publications.

McKinnon, Susan

1991 From a shattered sun: hierarchy, gender, and alliance in the Tanimbar Islands. Madison: The University of Wisconsin Press.

Needham, Rodney

1975 Polythetic classification: convergence and consequences. Man (ns) 10:349-369. 
Nooteboom, C.

1939 Versieringen van Manggaraische huizen. Tijdschrift voor Indische Taal-, Land-en Volkenkunde 79:221-238.

Otto, Ton

1994 Feasting and fighting: rank and power in pre-colonial Baluan. In M. Jolly and M. Mosko (eds), Transformations of hierarchy: structure, history and horizon in the Austronesian world. History and Anthropology (Special Issue) 7:223-239.

Sahlins, Marshall D.

1974 Stone age economics. London: Tavistock Publications.

Smedal, Olaf $\mathrm{H}$.

1992 Social anthropology, radical alterity, and culture. Canberra Anthropology 15(1):58-74.

2000 Sociality on display: the aesthetics of Ngadha houses. RES: Anthropology and Aesthetics 37:106-126.

2002 Ngadha relationship terms in context: description, analysis, and implications. Asian Journal of Social Science 30(3):493-524.

2009 On the value of the beast, or the limit of money: notes on the meaning of marriage prestations among the Ngadha, Central Flores (Indonesia). In K.M. Rio and O.H. Smedal (eds), Hierarchy: persistence and transformation in social formations, pp.269-297. Oxford and New York: Berghahn Books.

\section{ENDNOTES}

${ }^{1}$ Field research 1990-91 and 1993 totalling some 14 months was financed by the Norwegian Research Council for Science and the Humanities and by the Institute for Comparative Research in Human Culture, Oslo, and was conducted under the auspices of Lembaga Ilmu Pengetahuan Indonesia and Universitas Nusa Cendana, Kupang, Timor. The Department and Museum of Anthropology, University of Oslo, provided a six-month grant which enabled me to think through some of the material reported here. The first draft of this text was presented in Leiden in April 1996. I am grateful to Michael Vischer and the International Institute for Asian Studies for inviting and hosting me, to the Department of Social Sciences, University of Tromsø for financing my trip to Leiden, and to the Department of Social Anthropology, University of Bergen, for providing the opportunity to finalize the article.

2 The term 'House' (with capital ' $\mathrm{H}$ ') designates a social unit.

3 Arndt offers a long list of meanings of woé of which several have potential relevance here: first of all 'sib', 'family', 'clan', and Rangstufe ('level of social stratification' or 'place in hierarchy'); but also 'friend' (gender neutral), 'troupe', 'gathering', 'people'; 'to embrace', 'to bind', 'to draw in', 'to tie together' (1954:204; 1961:57). Realizing that 'House coalition network' hardly evokes the semantic range — nor of course the poetic potential - of the Ngadha term, I still search for a better English gloss.

4 Saka 'to ride'; $p u^{\prime} u$ 'trunk', 'stem', 'origin'; lobo 'top', 'tip'. The correct and complete designations of the two 'apex' Houses is as follows: sa'o pu'u saka pu'u and sa'o pu'u saka lobo. Thus there are two $s a^{\prime} o p u^{\prime} u$ for each woé. But houses are not usually referred to in this way; people always speak of the first as sa'o pu'u and of the second as saka lobo.

${ }^{5}$ I cannot deal here with the subtle symbolic significances of the $s u^{\prime} a a^{\prime} o$. 
${ }^{6}$ Unlike the neighbouring Keo 'clan' péo (see Forth, this volume), Ngadha ngadhu/ bhaga couples are exclusive to each woé.

${ }^{7}$ A word not, I think, cognate with the BI word baru 'new'; in (northeastern) Manggarai, immediately west of Ngadhaland, houses are referred to as mbaru (Nooteboom 1939:231). Erb remarks that until such a house has been ritually inaugurated it is called not mbaru but 'garden house' or simply 'forest' (1987:212).

8 In none of the villages where I did fieldwork is irrigated rice cultivation practised to any extent and none of the irrigated plots are worked by tenants. But I was informed that whenever someone rents such plots sharecropping is common; the landowner is likely to demand between one- and two-thirds of the produce, euphemistically referred to as fara 'do together'. Insofar as this information is reliable the two modes of 'land rent' are of decidedly different orders of magnitude, as people themselves stressed.

9 My remarks on this topic can be usefully compared with McKinnon's discussion of rank and its permutations in Tanimbar (1991:259-276), and my 'Table 1' with her 'Figure 11.1' (1991:262). It is clear that the principles in Tanimbar and in Ngadhaland have much in common; the main contrast appears to be the extreme severity with which Ngadha treat illegitimate unions.

${ }^{10}$ According to Arndt it sometimes happened that all affiliates of the woman's House were demoted — or demoted themselves voluntarily (1954:24-25).

11 Since Homo hierarchicus hovers in the background already I wish to juxtapose Ngadha hypergamy as described above and Dumont's discussion of the phenomenon as it occurs, admittedly with greater complexity, in India (1980:112-125). Among several arresting differences I note three. The first is that hypergamy in India usually takes place within a greater endogamous caste or subcaste group. The permitted status difference between the spouses, in other words, is one of degree rather than categorical. Secondly, in India the status discrepancy is usually neutralized normatively. The rule there is that the father's status, not the mother's, is transmitted to the couple's children who are, as it were, promoted. This feature inevitably produces motivations. Thirdly, according to Brahmanical ideology, marriage entails the 'gift of a maiden' and, for the gift to be meritoriously pure, no counter-prestation can be demanded, or even accepted.

Dumont comments, with respect to the Indian material, that the distinction between obligatory hypergamy and optional (or preferential, the most appropriate term with respect to the material at hand) hypergamy 'does not in fact have much interest' (1980:117) - a statement it is impossible to disagree with, referring as it does to a situation where every clan is differently ranked from any other, and one must marry outside the clan. However, had he discussed the Ngadha version of the principle - which may as well be called 'hypogamy prohibition' - he would, I think, have had to reconsider that statement, because the Ngadha permit, as I have mentioned, and even encourage, woé ('clan') and House ('clan segment') endogamy.

12 Arndt (1954:335-343 and 1960:242-250) provides further details on the prescriptions and proscriptions on nobles' behaviour. 